\title{
Study of demography and clinical profile of extracranial complications of chronic suppurative otitis media
}

\author{
Mallikarjun Patil $^{1 *}$, Shashidhar Suligavi², S. S. Doddamani ${ }^{3}$
}

\begin{abstract}
${ }^{1}$ Assistant Professor, ${ }^{2}$ Professor, ${ }^{3}$ Professor and HOD, Department of ENT, S Nijalingappa Medical College, Bagalkot, Karnataka, India
\end{abstract}

Received: 18 May 2018

Revised: 04 June 2018

Accepted: 05 June 2018

\section{*Correspondence:}

Dr. Mallikarjun Patil,

E-mail: drpatilmn@gmail.com

Copyright: (C) the author(s), publisher and licensee Medip Academy. This is an open-access article distributed under the terms of the Creative Commons Attribution Non-Commercial License, which permits unrestricted non-commercial use, distribution, and reproduction in any medium, provided the original work is properly cited.

\section{ABSTRACT}

Background: The complications of chronic suppurative otitis media (CSOM) are still prevalent in the developing countries like India. They pose a great challenge in the management. The objective of the study was to study the demographic pattern, symptomatology and pattern of extracranial complications of CSOM.

Methods: Patients of both sexes presenting with extra cranial complications of chronic suppurative otitis media were included. A proforma drafted for the study of these patients was used. The patients were subjected to investigations to confirm the diagnosis.

Results: In our study of 25 cases of extra cranial complications of CSOM, there were 14 females and 11 males.8 cases were in the age range of 11-20 years. Of the 25 cases, 22 belonged to the low income group and 3 to mid income group. Most common symptoms at presentation were otorrhoea, hearing loss, ear ache, postaural swelling and postaural discharge. Most cases were from rural area. Regarding extracranial complications, 10 cases (40\%) had subperiosteal abscess, $4(16 \%)$ mastoid fistula, $2(8 \%)$ acute mastoiditis, $3(12 \%)$ labyrinthine fistula, 2 (8\%) facial palsy alone and $3(12 \%)$ had multiple extracranial complications (facial palsy with mastoid fistula). Total facial palsy cases were $5(20 \%)$.

Conclusions: Most common age group affected were less than 20 yrs of age, females more affected than males, Low socio-economic group children were affected commonly. Ear discharge and ear pain were common presenting complaints. Subperiosteal abscess was most common extracranial complication followed by mastoid fistula, acute mastoiditis and facial palsy.

Keywords: Chronic suppurative otitis media, Demographics, Symptomatology, Ear discharge, Hearing loss, Extracranial complications

\section{INTRODUCTION}

The chronic discharging ear is still one of the common clinical condition that the otolaryngologist encounters in India. Before antibiotics were regularly available complications followed acute suppurative otitis medical (ASOM). But nowadays complications are more often seen in chronic suppurative otitis media. ${ }^{1}$
The symptoms of discharging ear are often neglected among the rural people and it is only when complications occur that the patient is taken to the major hospital for treatment. CSOM complications, despite its reduced incidence, still pose a great challenge in developing countries as the disease presents in the advanced stage leading to difficulty in management and consequently higher morbidity and mortality. The cholesteatoma and granulation tissue in tympanomastoid compartment are the major pathological processes causing these 
complications. To eradicate this chronic pathology, and to prevent complications, appropriate timely intervention by an otologist is required. ${ }^{1-3}$

The middle ear is surrounded by important structures like labyrinth, facial nerve, sigmoid sinus and brain. Spread of infection beyond its bony wall results in involvement of these structures and serious complications. ${ }^{2,4}$ With the advent of newer antibiotics, sophisticated methods of investigations like computed tomography and magnetic resonance imaging, advent of operating microscope and high technical skill in modern procedures, have considerably reduced the morbidity and mortality rates due to complications of CSOM. ${ }^{5}$

The present study has been carried out to highlight the demographics and symptomatology and the presenting pattern of extracranial complications.

\section{METHODS}

It was a cross sectional observational study conducted at a medical college hospital in North Karnataka during July 2009 to December 2010. The study was done after obtaining Institutional Ethics Committee approval and after obtaining informed consent. Consecutive 25 patients of both sexes presenting with extra cranial complications of chronic suppurative otitis media were included in the study. Patients with intracranial complications were excluded from the study. A thorough ENT and Head and Neck examination followed by systemic examination was done in all the patients. A provisional clinical diagnosis was made. The patients were subjected to investigations to confirm the diagnosis. The data collected was compiled into an excel spread sheet, analysed and finally the data was presented in percentages.

\section{RESULTS}

All the 25 patients were analysed regarding (1) age distribution, (2) sex distribution, (3) occupation, (4) socio-economic status, (5) rural and urban distribution, (6) symptomatology and (7) pattern of extracranial complications.

Table 1: Age distribution.

\begin{tabular}{|lll|}
\hline $\begin{array}{l}\text { Age group } \\
\text { (years) }\end{array}$ & $\begin{array}{l}\text { Number of } \\
\text { cases }\end{array}$ & Percentage (\%) \\
\hline 0 to 10 & 5 & 20 \\
\hline $\mathbf{1 1}$ to 20 & 8 & 32 \\
\hline $\mathbf{2 1}$ to 30 & 7 & 28 \\
\hline $\mathbf{3 1}$ to 40 & 2 & 8 \\
\hline $\mathbf{4 1}$ to 50 & 2 & 8 \\
\hline 51 to 60 & 1 & 4 \\
\hline Total & 25 & 100 \\
\hline
\end{tabular}

The age of patients in the study ranged from 6 years to 55 years and majority (80\%) were younger people under 30 years (Table 1). There were 14 females $(56 \%)$ and 11 males $(44 \%)$ in the present study.

Table 2: Occupation.

\begin{tabular}{|lll|}
\hline Occupation & $\begin{array}{l}\text { Number of } \\
\text { cases }\end{array}$ & $\begin{array}{l}\text { Percentage } \\
(\%)\end{array}$ \\
\hline Agriculturists & 7 & 28 \\
\hline Employee & 1 & 4 \\
\hline Housewives & 4 & 16 \\
\hline Students & 11 & 44 \\
\hline Drivers & 1 & 4 \\
\hline Handicraft workers & 1 & 4 \\
\hline Total & 25 & 100 \\
\hline
\end{tabular}

Students constituted nearly half of the participants $(44 \%)$ followed by farmers $(28 \%)$ and housewives $(16 \%)$ (Table 2).

In the present study, 22 cases $(88 \%)$ belonged to low income group and 3 cases $(12 \%)$ belonged to mid income group. In our study of 25 cases 17 (68\%) were from rural areas and $8(32 \%)$ cases were from urban areas. Ear discharge, hearing loss, ear ache and fever were the commonest presenting complaints (Table 3).

Table 3: Presenting symptoms.

\begin{tabular}{|lll|}
\hline Symptoms & $\begin{array}{l}\text { Number of } \\
\text { cases }\end{array}$ & $\begin{array}{l}\text { Percentage } \\
(\%)\end{array}$ \\
\hline Otorrhoea & 25 & 100 \\
\hline Ear ache & 13 & 52 \\
\hline Hearing loss & 18 & 72 \\
\hline $\begin{array}{l}\text { Swelling post aural } \\
\text { area }\end{array}$ & 10 & 40 \\
\hline Swelling at other sites & 1 & 4 \\
\hline $\begin{array}{l}\text { Discharge behind the } \\
\text { ear }\end{array}$ & 7 & 28 \\
\hline $\begin{array}{l}\text { Facial muscle } \\
\text { weakness }\end{array}$ & 5 & 20 \\
\hline Giddiness & 3 & 12 \\
\hline Fever & 13 & 52 \\
\hline Headache & - & - \\
\hline Vomiting & 3 & 12 \\
\hline
\end{tabular}

Ear discharge was complained by all the patients in the present study. All the patients had purulent, yellowish, foul smelling discharge present continuously. Some patients had occasional blood stained discharge. All these patients had a previous history of swelling behind the ear which was neglected and burst open spontaneously leading to postaural fistula. Facial weakness was complained in $5(20 \%)$ cases. The weakness was on same side of discharging ear. The facial weakness was gradual in onset. Giddiness and vomiting was present in $3(12 \%)$ cases. In these cases nystagmus was elicited on performing fistula test. 
Table 4: Pattern of extracranial complications.

\begin{tabular}{|lll|}
\hline $\begin{array}{l}\text { Extracranial } \\
\text { complications }\end{array}$ & $\begin{array}{l}\text { Number of } \\
\text { cases }\end{array}$ & $\begin{array}{l}\text { Percentage } \\
(\%)\end{array}$ \\
\hline Subperiosteal abscess & 10 & 40 \\
\hline Mastoid fistula & 4 & 16 \\
\hline Acute mastoiditis & 2 & 8 \\
\hline Luc's abscess & 1 & 4 \\
\hline Labyrinthine fistula & 3 & 12 \\
\hline Facial palsy alone & 2 & 8 \\
\hline $\begin{array}{l}\text { Multiple extracranial } \\
\text { complication (facial } \\
\text { palsy+mastoid fistula) }\end{array}$ & 3 & 12 \\
\hline Total & 25 & 100 \\
\hline
\end{tabular}

All the 25 cases had chronic suppurative media of atticoantral type. Tympanic membrane showed attic perforation in 10 cases and posterosuperior perforation in 15 cases. Granulations were present in 10 cases. The pattern of extracranial complications observed in the study is tabulated in Table 4.

\section{DISCUSSION}

\section{Age distribution}

Hossain and Kundu et al report in their study of 100 cases of extracranial complication majority cases were in group of 11-20 years. ${ }^{6}$

Osma and Sebahattin et al reported the average age of patients with complications as 16.4 years and 58 percent were under the age of 20 years.

In our study of 25 cases, the age of the patients varied between 6 to 55 years. Of these $8(32 \%)$ patients were between 11 to 20 years of age, which correlates with existing literature.

\section{Sex distribution}

In their of 100 cases of extracranial complications, Hossain and Kundu et al reported the male to female ratio of 1.94:1 and Osma and Sebahattin et al reported male to female ratio of $2: 16^{6,7}$

Shamboul et al have reported in their study of thirty three cases of complications of chronic suppurative otitis media, the female: male ratio of $2: 1^{8}$

In our study the female: male sex ratio is $1.27: 1$, it could probably be due to late presentation due to social and other factors. Our study correlates with study of Shamboul et al. ${ }^{8}$

\section{Socio-economic status}

Browning states that there is a relationship of chronic otitis media and low socio-economic group. ${ }^{9}$ Higher incidence is because of poor general health, malnutrition and overcrowding. In a study by Hossain and Kundu et al reported that majority of the patients came from low socio-economic class. ${ }^{6}$

In our study, 22 cases (88\%) belonged to the low income group and 3 cases (12\%) belonged to mid income group. None of them were in high income group in our study.

\section{Symptomatology}

Osma et al in their study of 93 cases of complications of chronic otitis media have reported otorrhoea to be the most common symptom present in all the patients $(100 \%){ }^{7}$ Other symptoms are otalgia in $31(33.3 \%)$, decreased hearing in 57 cases $(61.2 \%)$, post auricular swelling in cases $(26.8 \%)$, vertigo 7 cases $(7.5 \%)$, facial weakness 5 cases $(5.3 \%)$ and fever 65 cases (69.8\%). In our study of 25 cases of extracranial complications, the most common symptom is otorrhoea seen in all 25 cases $(100 \%)$. Other symptoms are otalgia $(52 \%)$, decreased hearing (72\%) post auricular swelling (40\%), vertigo (12\%), facial weakness (20\%), fever (52\%) and discharge from behind the ear $(24 \%)$. So our study correlates well with the present literature.

\section{Distribution of complications}

Osma et al have reported from 93 cases of extracranial complications, the distribution of complications as mastoid abscess 25 cases (69\%), labyrinthitis 5 cases $(12.8 \%)$, facial never paralysis 5 cases $(12.8 \%)$ and Bezold's abscess 4 cases $(10.3 \%)^{7}$

Hossain et al in their study of 100 cases of extracranial complications have reported the distribution of complications as a mastoid abscess (57\%), post aural fistula (28\%), purulent labyrinthitis 97\%), Bezold's abscess (4\%), facial nerve paralysis (35) and zygomatic abscess $(1 \%)$.

Kangsanarak et al have reported from their study of 102 cases of complications of chronic suppurative otitis media that subperiosteal abscess, facial paralysis and labyrinthitis to be the common extracranial complications, and $25 \%$ of the extracranial complications occurred more than two complications. ${ }^{10}$

In our study of 25 cases of extracranial complications, 10 cases $(40 \%)$ had subperiosteal abscess, 4 (16\%) mastoid fistula, $2(8 \%)$ acute mastoiditis, 1 (4\%) Luc's abscess, 3 (12\%) labyrinthine fistula, $2(8 \%)$ facial palsy alone and $3(12 \%)$ had multiple extracranial complications (facial palsy with mastoid fistula). Total facial palsy cases were $5(20 \%)$. Our study correlates well with the literature.

\section{CONCLUSION}

Most common age group affected were less than 20 yrs of age, females more affected than males, low socio- 
economic group children were affected commonly. Most cases belonged to the rural areas. Ear discharge, ear pain and hearing loss were common presenting complaints. Subperiosteal abscess was most common extracranial complication followed by mastoid fistula, acute mastoiditis and facial palsy and labyrinthine fistula.

Funding: No funding sources

Conflict of interest: None declared

Ethical approval: The study was approved by the Institutional Ethics Committee

\section{REFERENCES}

1. Dubey SP, Varqa L. Complications of chronic suppurative otitis media and their management. Laryngoscope. 2007;117:264-7.

2. Ludman H. Complications of suppurative otitis media. 6th ed. In: Scot- Browns Otolaryngology, Otology, Booth JB, ed. Oxford: Butterworth Heinemann. 1997;3:1-29.

3. Syms MJ, Luxford WM. Management of cholesteatoma: Status of the canal wall. Laryngoscpe. 2003;113:443-8.

4. Garap Jp, Dubey SP. Canal-down mastoidectomy: experience in 81 cases. Otol Neurotol. 2001;22:4516.

5. Yaniv E, Pocock R. Complications of ear disease. Clin Otolaryngol Allied Sci. 1988;13:357-61.
6. Hossain MM, Kundu SC, Haque MR, Shamsuzzaman AK, Khan MK, Halder KK. Extracranial complications of chronic suppurative otitis media. Mymensingh Med J. 2006;15:4-9.

7. Osma U, Cureoglu S, Hosoglu S. The complications of chronic otitis media: report of 93 cases. J Laryngol Otol. 2000;114:97-100.

8. Shamboul KM. An unusual prevalence of complications of chronic suppurative otitis media in young adults. J Laryngol Otol. 1992:106:874-7.

9. Browning GG. Aetiopathology of inflammatory conditions of the external and middle ear. 6th ed. Chapter 3. In: Scott -Brown's Otolaryngology, Booth JB ed. Oxford: oxford University press 1997;3:1-37.

10. Kangsanarak J, Fooanant S, Ruckphaopunt K, Navacharoen N, Teotrakul S, extracranial and intracranial complications of suppurative otitis media. Report of 102 cases. J Laryngol Otol. 1993;107:999-1004.

Cite this article as: Patil M, Suligavi S, Doddamani SS. Study of demography and clinical profile of extracranial complications of chronic suppurative otitis media. Int J Otorhinolaryngol Head Neck Surg 2018;4:977-80. 